\title{
Improvement in phosphorus nutrition of wheat plants grown in a calcareous sandy soil by incorporating chemical phosphorus fertilizer with some selected organic substances
}

\author{
Adil MIHOUB ${ }^{1,2}$, Abu El-Eyuoon Abu Zied AMIN ${ }^{3}$, Naeem ASIF ${ }^{4}$, Mustapha DADDI BOUHOUN ${ }^{5}$
}

Received August 27, 2018; accepted May 24, 2019.

Delo je prispelo 27. avgusta 2018, sprejeto 24. maja 2019.

\begin{abstract}
Improvement in phosphorus nutrition of wheat plants grown in a calcareous sandy soil by incorporating chemical phosphorus fertilizer with some selected organic substances

Abstract: Established fertilizer recommendations for wheat is urgently required to enhance the application efficiency of commercial phosphorus (P) fertilizers. This study evaluated the effect of inorganic $\mathrm{P}$ combined with some organic supplements i.e., citric acid (CA) or pigeon manure juice $(\mathrm{PMJ})$, on alkaline-calcareous soil as well as plant measurements and phosphorus efficiency parameters of wheat (Triticum durum 'Boussalem'). Different concentrations of P in solution i.e., $0.05,0.10,0.15,0.20$, and $0.40 \mathrm{mg} \mathrm{l}^{-1}$, were worked out theoretically using the Freundlich model. A greenhouse study was conducted on a permanent layout with three replicates. As a result, phosphorus in the control was $0.493 \mathrm{mg}$ $\mathrm{P}$ pot $^{-1}$. However, in amended pots with organic substances, the averages of $\mathrm{P}$ uptake were 0.701 and $0.785 \mathrm{mg} \mathrm{P}^{\mathrm{P}} \mathrm{pt}^{-1}$, respectively for PMJ and CA treatments. A lower P requirement of 0.195 and $0.245 \mathrm{mg} \mathrm{P}^{-1}$ may be required in CA and PMJ treatments, compared to the control treatments $(0.345 \mathrm{mg} \mathrm{P}$ $\left.\mathrm{l}^{-1}\right)$. In addition, the phosphorus absorption efficiency (PAE) was higher in the CA and PMJ treatments. So, it is recommended to apply $\mathrm{P}$ fertilizers with poultry manure juice as an alternative solution in order to improve the efficiency of inorganic $\mathrm{P}$ fertilizers and consequently reduce their application rates in alkaline calcareous soils.
\end{abstract}

Key words: organic supplements; durum wheat; phosphorus uptake; phosphorus use efficiency; calcareous soil
Izboljšanje prehranjenosti trde pšenice $s$ fosforjem na peščenih apnenčastih tleh $\mathrm{z}$ dodajanjem izbranih organskih snovi mineralnim fosforjevim gnojilom

Izvleček: Obstoječa priporočila za gnojenje trde pšenice potrebujejo nujne izboljšave za doseganje večje učinkovitosti komercialnih fosforjevih gnojil. V raziskavi so ovrednoteni učinki kombiniranega gnojenja $\mathrm{z}$ anorganskim $\mathrm{P}$ in organskimi dodatki kot sta citronska kislina (CA) ali raztopina piščančjega gnoja (PMJ), na alkalnih apnenčastih tleh kot tudi meritve rastlinskih parametrov in učinkovitosti izrabe fosforja pri trdi pšenici (Triticum durum 'Boussalem'). Učinki različnih koncentracij $\mathrm{P}$ v raztopini, $0,05,0,10,0,15,0,20$, in $0,40 \mathrm{mg} \mathrm{l}^{-1}$, so bili ovrednoteni s Freundlichovim modelom. Raziskava v rastlinjaku je bila izvedena $s$ trajno postavitvijo $\mathrm{v}$ treh ponovitvah. Privzem P v kontroli je bil 0,493 mg P na lonec. V loncih $\mathrm{z}$ dodatki organskih snovi je bil poprečni privzem $\mathrm{P} 0,701 \mathrm{mg}$ $\mathrm{P}$ na lonec za obravnavanje s piščančjim gnojem in $0,785 \mathrm{mg} \mathrm{P}$ na lonec za obravnavanje s citronsko kislino. Pri obravnavanjih $\mathrm{z}$ dodatki organskih snovi so bile potrebne manjše količine $\mathrm{P}, 0,195 \mathrm{mg} \mathrm{P}^{-1} \mathrm{za}$ obravnavanje s CA in $0,245 \mathrm{mg} \mathrm{P}^{-1} \mathrm{za}$ obravnavanje s PMJ, v primerjavi s kontrolo $\left(0,345 \mathrm{mg} \mathrm{P} \mathrm{l}^{-1}\right)$. Učinkovitost absorpcije fosforja (PAE) je bila večja pri obravnavanjih CA in PMJ. Na osnovi teh rezulatov se priporoča uporaba $\mathrm{P}$ gnojil $\mathrm{z}$ izvlečki piščančjega gnoja kot alternativna rešitev za izboljšanje učinkovitosti anorganskih $\mathrm{P}$ gnojil in posledično zmanjšanje njihovih količin na alkalnih apnečastih tleh.

Ključne besede: organski dodatki; trda pšenica; privzem fosforja; učinkovistost izrabe fosforja; apnenčasta tla

\footnotetext{
Scientific and Technical Research Center for Arid Areas, Algeria.

2 Corresponding author, e-mail: adilmihoub15@yahoo.com

3 Assiut University, Faculty of Agriculture, Soils and Water Department, Assiut, Egypt

4 Nuclear Institute for Agriculture and Biology, Faisalabad, Pakistan

5 University of Kasdi Merbah, Department of Agronomic Sciences, Ouargla, Algeria
} 


\section{INTRODUCTION}

Calcareous sandy soils in arid regions suffer from poor physical and chemical fertility because of their low organic matter content and low water retention beside their poverty (Brady \& Weil, 1999). Calcareous soils containing insufficient amounts of nutrients not only produce economically unacceptable yields, but some most important inputs, particularly $\mathrm{P}$ are also used less effectively.

It is well known that wheat is a major cereal crop that feeds most of the world's population, especially the Mediterranean region. It is one of the largest cereal crops in terms of cultivated areas around the world (Royo et al., 2017).

Phosphorus is one of the more expensive nutrients required for wheat production and its use efficiency is induced by soil properties, especially in calcareous soils, which are dominant in the Mediterranean region. In fear for P deficiency, excess P fertilizers are routinely applied by farmers for producing wheat. However, wheat plants take and use a small amount of phosphorus applied. P use efficiency (PUE) in wheat is only about $5 \sim 10 \%$ in the year of addition, where most of the phosphorus added to the soil is fixed (Ma et al., 2005).

Modern agriculture aims to reduce inputs without reducing yield and quality (Bulgari et al., 2014). Identification of a suitable alternate technology that can avoid excessive application and improve P use efficiency in agriculture is urgently required.

Additions of farmyard manure to calcareous sandy soil caused significant increases in the amount of phosphorus availability (Amin, 2018), it increases because the organic amendments consisting many organic acids (Delgado et al., 2002) and which in turn increases available $\mathrm{P}$ for plant via inhibiting $\mathrm{Ca}$ phosphate precipitation and mobilizing native soil P (Mohanty et al., 2006). Many studies have reported $\mathrm{P}$ sorption inhibition due to site competition and metal complexation by organic acids (Uburger et al., 2011), animal and green manures (Alamgir et al., 2012) and biosolids (Pinerio et al., 2009).

At the present time, there is an urgent need to seek strategies by which P fertilizers can be used more effectively in soils rich in calcium carbonate of Algeria, thus, attempting to complement the previous knowledge on the optimization of phosphorus fertilization in the calcareous soil of Algeria (Mihoub et al., 2016; Mihoub et al., 2017; Mihoub et al., 2018). So, the objectives of this research were to investigate the beneficial effect of integrating $\mathrm{P}$ fertilizer with organics substances on combating $\mathrm{P}$ deficiency and reducing the reliance on phosphorus fertilizers for wheat cropped on alkaline-calcareous soils.

\section{MATERIALS AND METHODS}

\subsection{SOIL SAMPLE COLLECTION AND PREPARA- TION}

Soil samples were collected from the surface layer (at 0-30 $\mathrm{cm}$ depth), belonging to a major soil types in Oued Righ (southern Algeria) as Psamment with loamysand textural class located at $33^{\circ} 29^{\prime} 47^{\prime \prime} \mathrm{N}, 5^{\circ} 39^{\prime} 39^{\prime \prime} \mathrm{E}$, this covered a wide range of soil types and characteristics in Oued Righ area. The soil samples were air-dried and ground to pass through a $2 \mathrm{~mm}$ - sieve prior to analysis. Samples were analyzed for physicochemical properties like particle size distribution by the pipette method, $\mathrm{pH}$ using 1:2.5 soil-water ratio, calcium carbonate (Calcimeter Bernard Method) (Loeppert \& Dohnal, 1996) and organic carbon content through loss on ignition. Plant

Table 1: Model and linear form of fitted modified Freundlich equation used to compute phosphorus $(\mathrm{P})$ rates from the theoretical soil solution P levels

\begin{tabular}{|c|c|c|}
\hline Freundlich equation & $\mathrm{P}$ in soil solution $\left(\mathrm{mg} \mathrm{P}^{-1}\right)$ & Computed $\mathrm{P}$ rates ( $\mathrm{mg} \mathrm{P} \mathrm{kg}^{-1}$ soil) \\
\hline Linear form & Native & 0 \\
\hline \multicolumn{3}{|l|}{$y=0.601 x+5.578$} \\
\hline \multicolumn{3}{|l|}{ Model form $\left[\mathrm{X}=\mathrm{aC}^{\mathrm{n}}\right]$} \\
\hline \multicolumn{3}{|l|}{$X=264.8 C^{0.601}$} \\
\hline & 0.05 & 44 \\
\hline & 0.10 & 66 \\
\hline & 0.20 & 101 \\
\hline & 0.40 & 153 \\
\hline
\end{tabular}


available $\mathrm{P}$ was extracted with $0.5 \mathrm{~N} \mathrm{NaHCO}_{3}$ (Watanabe \& Olsen, 1965) and concentration was measured by the colorimetric molybdate-ascorbic acid method (Murphy \& Riley, 1962). Studied soil was classified according to USDA soil taxonomy. All analyses were run in triplicate.

\subsection{PHOSPHORUS ADSORPTION ISOTHERM}

Phosphorus adsorption characteristics of the soil were determined in a laboratory. A $4 \mathrm{~g}$ soil sample was equilibrated in $40 \mathrm{ml} 0.01 \mathrm{M}$ calcium chloride $\left(\mathrm{CaCl}_{2}\right)$ containing $0,10,20,30,50$, and $100 \mu \mathrm{g} \mathrm{P} \mathrm{ml}^{-1}$ as $\mathrm{KH}_{2} \mathrm{PO}_{4}$ and the soil solution ratio was 1:10. Three to four drops of toluene $\left(\mathrm{C}_{6} \mathrm{H}_{5} \mathrm{CH}_{3}\right)$ were added to inhibit microbial activity. The tubes were incubated at $25{ }^{\circ} \mathrm{C}$ for one week with 2 hours shaking every day on a reciprocating shaker. At the end of the incubation period, the tubes were centrifuged at $4000 \mathrm{rpm}$ for $10 \mathrm{~min}$ and filtered. The $\mathrm{P}$ content in the supernatant solution was measured spectrophotometrically using Jenway 6310 spectrophotometer at a wavelength of $800 \mathrm{~nm}$ by the colorimetric molybdate-ascorbic acid method (Murphy \& Riley, 1962). The amount of $\mathrm{P}$ adsorbed (X) was calculated from the difference between $\mathrm{P}$ added and the equilibrium $\mathrm{P}$ concentration (C). A logarithmic relationship between (C) and (X) was constructed. Data from the linear log equation were fitted to the following modified Freundlich equation (Fox \& Kamprath, 1970), and P rates were computed against theoretical soil solution P levels (Table 1).

Adsorption isotherm was modulated by the general form of Freundlich equation as follows:

$$
\mathrm{X}=\mathrm{aC}^{\mathrm{n}}
$$

Where: $\mathrm{X}$ : the amount of $\mathrm{P}$ sorbed per gram of soil

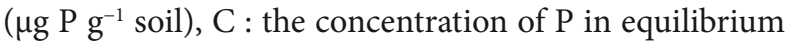
solution $\left(\mathrm{mg} \mathrm{l}^{-1}\right),(a)$ : a constant related to sorption capacity $\left(\mu \mathrm{g} \mathrm{g}^{-1}\right)$, and $n$ : phosphate sorption energy (ml $\left.\mathrm{g}^{-1}\right)$.

\subsection{GREENHOUSE EXPERIMENT}

An experiment was conducted at the scientific and technical research center for arid areas (CRSTRA), Algeria using durum wheat 'Boussalem' as a test crop which was planted in pots each containing $1 \mathrm{~kg}$ of soil. Treatments consisted of control and four theoretical doses of $\mathrm{P}$ application rates to provide desired range of $\mathrm{P}$ levels in soil solution were calculated from the Freundlich equations cited above. The treatments included the combinations of inorganic P fertilizer as triple super phosphate
(TSP) containing $46 \% \mathrm{P}_{2} \mathrm{O}_{5}$ with two organic substances: citric acid solution $(\mathrm{CA})$ at $0.01 \mathrm{M}$ and pigeon manure juice $(\mathrm{PMJ})$ at $1 / 100(\mathrm{w} / \mathrm{v})$ were extracted according to Ingham (2002) procedure. Some physic-chemical characteristics of theses prepared substances were summarized in Table 2. Used inorganic fertilizer was finely milled to a fine powder and applied uniformly mixing with the soil in each pot. Fertilizer application rates were $0,44,66,101$, and $153 \mathrm{mg} \mathrm{P} \mathrm{kg}^{-1}$ corresponding to soil solution $\mathrm{P}$ concentration of between $0,0.05,0.10,0.20$, $0.40 \mathrm{mg} \mathrm{P}^{-1}$. Nitrogen and potassium were applied as $\left(\mathrm{NH}_{4}\right)_{2} \mathrm{SO}_{4}(21 \% \mathrm{~N})$ and $\mathrm{K}_{2} \mathrm{SO}_{4}\left(50 \% \mathrm{~K}_{2} \mathrm{O}\right)$, respectively to all experimental pots at rates equivalent to $100 \mathrm{mg}$ $\mathrm{N} \mathrm{kg}^{-1}$ soil and $100 \mathrm{mg} \mathrm{K} \mathrm{kg} \mathrm{K}^{-1}$ soil.

The pots were placed in the field and arranged in a randomized complete block design (RCBD) with three replications. Before sowing wheat seeds, the treatments were wetted to field capacity by applying $100 \mathrm{ml} \mathrm{pot}^{-1}$ of both organic substances and left to incubate for one week to remove the effects of sample handling (sieving, drying and mixing) and to provide homogeneous mixtures between treatments and organic amendments. Five seeds of wheat were then sown in each pot at a depth of $2.5 \mathrm{~cm}$. The plants were thinned after establishment to two plants per pot. The pots were watered using distilled water to maintain adequate soil moisture for the growing plants as required throughout the growing period and watering was differentiated according to field capacity of each soil.

\subsection{PLANT MEASUREMENTS AND PHOSPHORUS EFFICIENCY PARAMETERS}

The shoot's length (SL, cm) was measured directly in the pots, and then the shoots were harvested after 90 days of seeding by cutting the shoots $0.5 \mathrm{~cm}$ above the soil surface, and then the roots were separated from the soil manually to measure the length of the root $(\mathrm{RL}, \mathrm{cm})$. The harvested wheat shoots were dried at $80{ }^{\circ} \mathrm{C}$ for 72 hours, then we weighed shoot dry matter yield (SDM, g pot ${ }^{-1}$ ). The dried wheat shoots were milled to a fine powder and it burned in a muffle furnace for four h at $550{ }^{\circ} \mathrm{C}$ tell turn-

Table 2: Some chemicals characteristics of organics substances used

\begin{tabular}{lcc}
\hline Parameters & CA $(0.01 \mathrm{M})$ & PMJ $(1 / 100: \mathrm{w} / \mathrm{v})$ \\
\hline $\mathrm{pH}$ & 2.74 & 8.2 \\
EC, $\mathrm{dS} \mathrm{m}^{-1}$ & 0.78 & 16.02 \\
Organic C, \% & 37.7 & n.d \\
Total N, $\mathrm{mg} \mathrm{l}^{-1}$ & n.d & 101 \\
\hline
\end{tabular}

n.d mean not determined 
ing to ash. The ash was dissolved in $2 \mathrm{M} \mathrm{HCl}$ and shoot $\mathrm{P}$ concentration (SPC, \%) determined calorimetrically using phospho-vanadomolybdate. Soil available $\mathrm{P}$ in soil samples was extracted with $0.5 \mathrm{~N} \mathrm{NaHCO}_{3}$ (Watanabe \& Olsen, 1965) and $\mathrm{P}$ in the extractant was determined by using the ammonium molybdate-ascorbic acid method described by Murphy and Riley (1962). Phosphorus uptake (PU, mg $\mathrm{P}$ pot $^{-1}$ ) was calculated by the following equation:

$$
\mathrm{PU}=\mathrm{SPC} \times \mathrm{SDM}
$$

Phosphorus absorption efficiency (PAE, mg $\mathrm{mg}^{-1}$ soil P) was calculated as follows (adapted from Castillo et al., 2013):

$\mathrm{PAE}=\mathrm{PU} /($ available $\mathrm{P})$

\subsection{DATA ANALYSIS}

The data collected were pooled up and statistically analyzed by analysis of variance (ANOVA) technique under randomized complete block design. Various statistical computations were performed using Statsoft Statistica Software, $10^{\text {th }}$ Edition (Statsoft, Tulsa OK).

\section{RESULTS AND DISCUSSION}

Selected physicochemical properties of soil are listed in Table 3 . The soil was loamy sand, mildly alkaline and low in organic matter content, typical for calcareous soils. This soil contains high calcium carbonate $\left(20.8 \% \mathrm{CaCO}_{3}\right)$. The low available $\mathrm{P}$ suggests apparent $\mathrm{P}$ deficiency in soil under study.

\subsection{SHOOT AND ROOT LENGTH OF WHEAT}

There were no significant differences in the shoot and root length among $\mathrm{P}$ rates and their combinations with organic materials. While, interaction treatments $x$ $P$ rates indicated significant difference $(p<0.05)$ in the
Table 3: Some physicochemical properties of the experimental soil used in the study

\begin{tabular}{llc}
\hline Properties & Unit & Value \\
\hline Sand & $\%$ & 81.3 \\
Silt & $\%$ & 13.3 \\
Clay & $\%$ & 5.4 \\
USDA texture & - & Loamy sand \\
USDA soil taxonomy (Suborder) $^{-}$ & Psamment \\
$\mathrm{pH}_{\text {water (1:2.5) }}$ & - & 7.88 \\
$\mathrm{EC}_{(1: 5)}$ & $\mathrm{dS} \mathrm{m}^{-1}$ & 1.63 \\
$\mathrm{CaCO}_{3}$ & $\%$ & 20.8 \\
Organic matter & $\%$ & 0.87 \\
Available-P & $\mathrm{mg} \mathrm{kg}^{-1}$ & 1.48 \\
Water-soluble P & $\mathrm{mg} \mathrm{kg}^{-1}$ & 0.10 \\
\hline
\end{tabular}

plant shoot length. However, when compared with the control the shoot and roots length were significantly greater for all the treatments with $\mathrm{P}$ fertilizer and their combination with each of organic materials than those for the control (Table 4).

Mean of shoot length (SL) were increased from $18 \mathrm{~cm}$ in control treatments to 18.2 and $19.5 \mathrm{~cm}$ in treatments with CA and PMJ, respectively. Mean values of RL were varied from $14.8 \mathrm{~cm}$ in control treatments to 15.9 and $16.2 \mathrm{~cm}$ when adding CA and PMJ, respectively (Table 5).

The results show that the hypothesis (at a given $\mathrm{P}$ rate combined with organic materials will increase biological parameters, available $\mathrm{P}$ more than inorganic- $\mathrm{P}$ addition solely) can be accepted. Shoot and roots length were significantly greater for all the treatments with $\mathrm{P}$ fertilizer and its combination with each of organic materials. Generally, the optimum value of the shoots and roots length has been recorded by using PMJ. This is most likely due to the $\mathrm{N}$ added with pigeon manure juice (101 $\mathrm{mg} \mathrm{l}^{-1}$ ) which could enhance the vegetative growth of wheat. Growth increment in the PMJ treatments could also be the result of increased microbial growth and activity induced by $\mathrm{C}$ addition with the residues which may have included plant growth-promoting microorganisms. Waraich et al. (2015) reported 17.76 and $12.98 \mathrm{~cm}$ as the

Table 4: ANOVA, F-values, and level of significance for treatments, $P$ rates and interactions

\begin{tabular}{|c|c|c|c|c|c|c|c|c|}
\hline SOV & $\mathrm{df}$ & SL & $\mathrm{RL}$ & SDM & SPC & $\mathrm{PU}$ & Available-P & PAE \\
\hline Treatments & 2 & $1.40^{\mathrm{N} . \mathrm{S}}$ & $0.92^{\text {N.S }}$ & $1.94^{\mathrm{N} . \mathrm{S}}$ & $222.41^{* * *}$ & $43.71^{* * *}$ & $320.76^{* * *}$ & $24.12^{* * *}$ \\
\hline$P$ rate & 4 & $1.95^{\mathrm{N} . S}$ & $1.22^{\mathrm{N} . \mathrm{S}}$ & $7.64^{* * *}$ & $128.04^{* * *}$ & $25.74^{* * *}$ & $463.64^{* * *}$ & $13.2^{* * *}$ \\
\hline Treatments $\times \mathrm{P}$ rate & 8 & $3.15^{* *}$ & $1.16^{\mathrm{N} . \mathrm{S}}$ & $7^{* * *}$ & $16.63^{* * *}$ & $4.77^{* * *}$ & $153.68^{* * *}$ & $8.1^{* * *}$ \\
\hline
\end{tabular}

N.s Stands not significant; ${ }^{* *}$ Stands significant at $p<0.05 ;{ }^{* * *}$. Stands significant at $p<0.01$ 
Table 5: Shoot and root length, biomass accumulation and $\mathrm{P}$ uptake as affected by various treatments

\begin{tabular}{|c|c|c|c|c|c|c|}
\hline \multirow{2}{*}{$\begin{array}{l}\text { Treatments } \\
\text { Control }\end{array}$} & \multicolumn{2}{|c|}{ Soil sol. P $\left(\mathrm{mg} \mathrm{l}^{-1}\right)$ SL $(\mathrm{cm})$} & \multirow{2}{*}{$\begin{array}{l}\mathrm{RL}(\mathrm{cm}) \\
14\end{array}$} & \multirow{2}{*}{$\begin{array}{l}\text { SDM }\left(\mathrm{g} \mathrm{pot}^{-1}\right) \\
0.252\end{array}$} & \multirow{2}{*}{$\begin{array}{l}\text { SPC (\%) } \\
0.04\end{array}$} & \multirow{2}{*}{$\begin{array}{l}\mathrm{PU}\left(\mathrm{mg} \mathrm{pot}^{-1}\right) \\
0.101\end{array}$} \\
\hline & 0.00 & 15.3 & & & & \\
\hline & 0.05 & 21.5 & 12 & 0.586 & 0.08 & 0.469 \\
\hline & 0.10 & 20.3 & 17.8 & 0.467 & 0.119 & 0.556 \\
\hline & 0.20 & 15.5 & 13.4 & 0.364 & 0.126 & 0.459 \\
\hline & 0.40 & 17.5 & 16.8 & 0.475 & 0.137 & 0.651 \\
\hline & Mean & 18 & 14.8 & 0.428 & 0.100 & 0.428 \\
\hline \multirow[t]{6}{*}{ PMJ } & 0.00 & 19.3 & 14.3 & 0.409 & 0.15 & 0.614 \\
\hline & 0.05 & 16.3 & 15.1 & 0.342 & 0.124 & 0.424 \\
\hline & 0.10 & 21.3 & 17.9 & 0.550 & 0.179 & 0.985 \\
\hline & 0.20 & 21.1 & 15.9 & 0.588 & 0.199 & 1.170 \\
\hline & 0.40 & 19.5 & 17.8 & 0.493 & 0.177 & 0.873 \\
\hline & Mean & 19.5 & 16.2 & 0.476 & 0.165 & 0.785 \\
\hline \multirow[t]{6}{*}{$\mathrm{CA}$} & 0.00 & 19.4 & 15 & 0.375 & 0.129 & 0.484 \\
\hline & 0.05 & 14 & 18 & 0.586 & 0.075 & 0.440 \\
\hline & 0.10 & 19.5 & 13.4 & 0.443 & 0.214 & 0.948 \\
\hline & 0.20 & 21 & 15.8 & 0.545 & 0.241 & 1.313 \\
\hline & 0.40 & 17 & 17.3 & 0.371 & 0.198 & 0.735 \\
\hline & Mean & 18.2 & 15.9 & 0.464 & 0.171 & 0.793 \\
\hline
\end{tabular}

Each value is the mean of three replicates

maximum shoot and root length, respectively for wheat after 40 days of sowing. The combination of $\mathrm{P}$ fertilizer with both organic solutions generally improves the availability of P in the soil which stimulates wheat's root development. Kelly et al. (1979) also showed that the root length increased with increasing P rates. P can also stimulate development of lateral roots (Brady \& Weil, 2008).

\subsection{BIOMASS ACCUMULATION}

All treatments in combination with organic substances caused significant increase in the dry yield of wheat $(p<0.01)$ compared to the control treatment. The nature of the response to the added $\mathrm{P}$ depended on the soil and the change in biomass yield with $\mathrm{P}$ addition was estimated by plotting SDM against soil solution $\mathrm{P}$ levels. In control treatments mean biomass yield was $0.428 \mathrm{~g} \mathrm{SDM} \mathrm{pot}^{-1}$. However, it ranged from $0.476 \mathrm{~g} \mathrm{SDM} \mathrm{pot}^{-1}$ for treatments with PMJ to $0.464 \mathrm{~g} \mathrm{SDM} \mathrm{pot}^{-1}$ for treatments with CA (Table 5). Approximately $11.21 \%$ and $8.41 \%$ of the mean SDM yields were increased by combining inorganic $\mathrm{P}$ fertilizer with PMJ and CA, respectively over control where no external fertilizer $\mathrm{P}$ was applied. This is most likely due to the application of organic substance (PMJ) which provide supplement nutrients $\left(\mathrm{N}=101 \mathrm{mg} \mathrm{l}^{-1}\right)$ to plant and increase growth parameters of wheat crop. Li et al. (2003) indicated a positive interaction between nitrogen and phosphorus on wheat growth. Waraich et al. (2015) recorded $1.5 \mathrm{~g}$ as the maximum wheat shoot dry mass after 40 days of sowing. Wheat dry matter production is influenced by a number of factors including climatic conditions, the potential fertility of the soil, the dose of seedlings (density) and the variety. For a good result, it is necessary to provide the soil by nutrients as the needs of cultivation in particular, intervention dates. Our results showed that the production of dry matter is influenced by mineral fertilization. Total yield of biomass gradually increased with higher $P$ rates. These results are consistent with those obtained by Mehdi et al. (2007). Deng et al. (2014) found similar results for maize crop. It was reported that the increase in dry matter production following $\mathrm{P}$ application is a result of improved root system (Pellerin et al., 2000).

\subsection{WHEAT TISSUE P CONCENTRATIONS AND P UPTAKE}

ANOVA indicated significant difference $(p<0.01)$ of $\mathrm{P}$ concentration in the plant tissue of wheat between 
inorganic $\mathrm{P}$ combined with organic materials. Trends of plant tissue $\mathrm{P}$ concentration were similar to those of biomass yield which were curvilinear for both treatments with plant $\mathrm{P}$ concentration increasing with increased levels of $\mathrm{P}$ and organic substances addition. $\mathrm{P}$ concentration has recorded an average of $0.100 \%$ in control treatment. However, $\mathrm{P}$ concentrations in amended soil were increased to $0.165 \%$ and $0.171 \%$ for PMJ and CA treatments. respectively. Generally, the maximum phosphorus concentration in wheat shoot was 0.199 and $0.241 \%$ which was achieved at an equilibrium $\mathrm{P}$ concentration of $0.20 \mathrm{mg} \mathrm{P}^{-1}$ reported in the literature to be a threshold for many crops. When shoot $\mathrm{P}$ concentrations in the present study were compared to those previously published. It appears that at all levels of $\mathrm{P}$ supply, shoot $\mathrm{P}$ concentrations in wheat were within the adequate range (0.1 and $0.4 \%$; Grant et al., 2004). Sarfraz et al. (2009) reported $0.145 \%$ as shoot $\mathrm{P}$ concentration of wheat at $0.5 \mathrm{mg} \mathrm{P}^{-1}$ in soil solution. Increasing $\mathrm{P}$ rates and organic substances addition led to an increase of $\mathrm{P}$ concentration. These results are in agreement with those of Heidi (2011) who used different levels of poultry manure as a soil amendment. His results showed that $\mathrm{P}$ concentration was increased in treatments where only poultry manure was applied as an organic source. Phosphorus uptake was enhanced with increased levels of P and organic substances addition. ANOVA indicated significant difference $(p<0.01)$ between inorganic $\mathrm{P}$ in combination with organic materials for $\mathrm{P}$ uptake of wheat. The $\mathrm{P}$ uptake in the control pots was $0.428 \mathrm{mg} \mathrm{P}^{\mathrm{P}} \mathrm{pot}^{-1}$. However, in amended pots with organic substances, the average of $\mathrm{P}$ uptake was 0.785 and $0.793 \mathrm{mg} \mathrm{P}^{\mathrm{P}}$ pot $^{-1}$ after addition of PMJ and CA amendments, respectively (Table 5). Kizilgoz \& Sakin (2010) recorded $1.42 \mathrm{mg} \mathrm{pot}^{-1}$ as the maximum $\mathrm{P}$ uptake by wheat grown in a calcareous soil supplied with $120 \mathrm{mg} \mathrm{P} \mathrm{kg}^{-1}$.

\subsection{PLANT AVAILABILITY OF P}

Available $\mathrm{P}$ was increased by the combination of $\mathrm{P}$ with organic materials, the very lower values of available$\mathrm{P}$ were recorded in the control treatments where $\mathrm{P}$ was applied solely. However, integration of either inorganic $\mathrm{P}$ with organic materials increased $\mathrm{P}$ availability, where the highest available-P values were recorded in PMJ and CA treatments with 20.55 and $17.80 \mathrm{mg} \mathrm{kg}^{-1}$, respectively and the increase in available-P due to the combined treatments of PMJ and CA was 27.87 and $10.76 \%$. respectively over control (Fig. 1).

Organic supplements have been reported to increase $\mathrm{P}$ availability in P-fixing soils (Iyamuremye \& Dick, 1996; Guppy et al., 2005; Agbenin \& Igbokwe, 2006; Gichangi, 2009). Combining $P$ fertilizer with tested organic substances limits direct exposure of inorganic $\mathrm{P}$ to soil. Thus, decreasing sorption reactions and increasing $\mathrm{P}$ availabil-

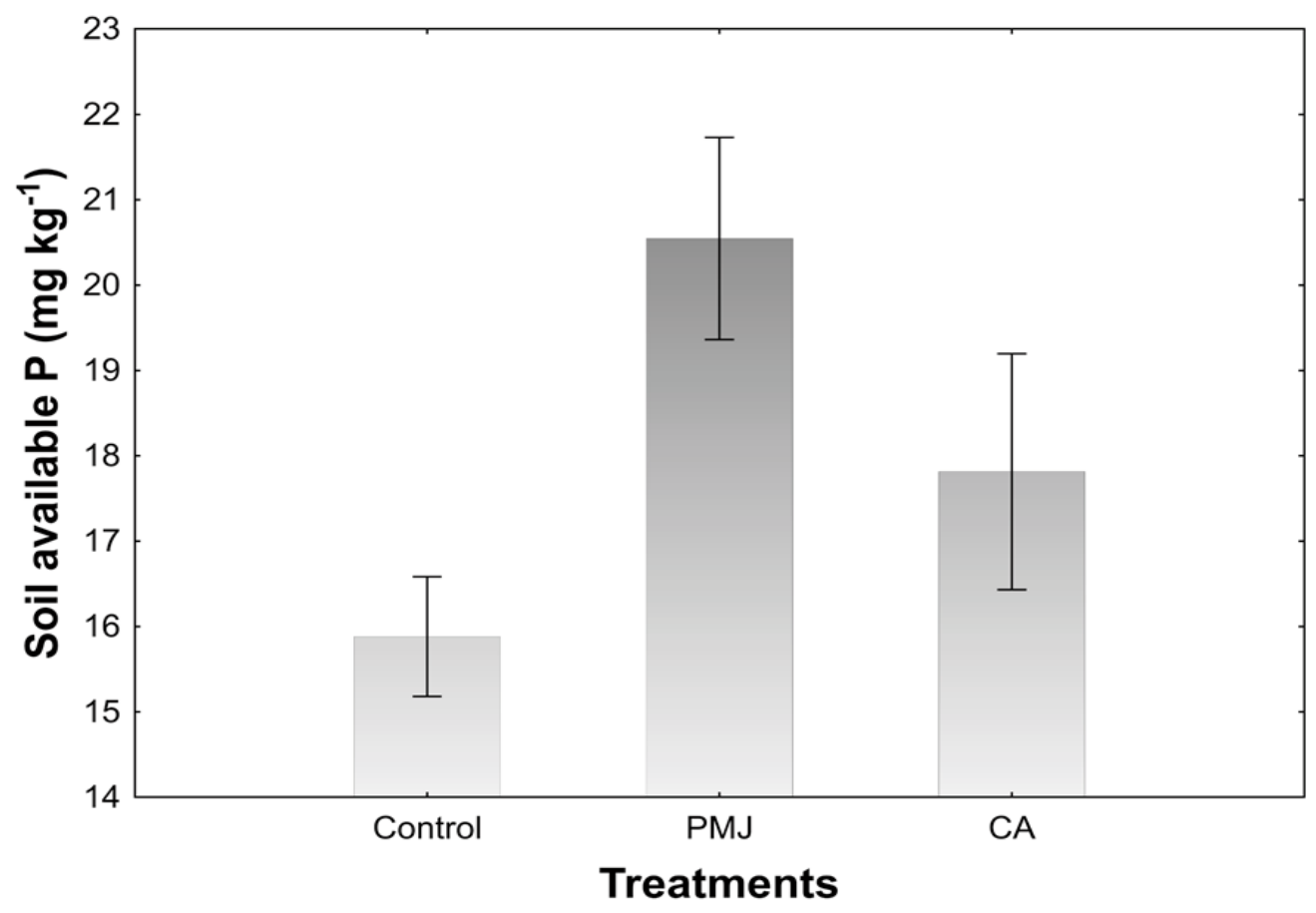

Figure 1: Soil phosphorus availability as affected by various treatments. Vertical bars denote \pm standard deviation. 
ity to plant (Moradi et al., 2012). The formation of protective layer around inorganic $\mathrm{P}$ particles by physically overlapping of $\mathrm{P}$ ions or exchange sites thus inhibits their reactivity to some extent (Von Wandruszka, 2006). Organic anions derived from PMJ decomposition as oxalates react with free $\mathrm{Ca}^{2+}$ ions in soil and convert it to precipitate of calcium oxalate $\left(\mathrm{CaC}_{2} \mathrm{O}_{4}\right)$. Thus, suppressing the activity of $\mathrm{Ca}^{2+}$ in soil and increasing $\mathrm{P}$ availability for plant and its uptake (Ström et al., 2001). Together, these mechanisms together lower the $\mathrm{P}$ fixation process and maintain higher $\mathrm{P}$ availability for planting in calcareous soils (Ma \& Xu, 2010). In the present study, the control treatments showed that an average $92 \%$ of the applied $\mathrm{P}$ becomes non-extractable after 90 days in studied calcareous soil. However, a decrease of 88 and $89 \%$ in extractable $\mathrm{P}$ was noticed in amended soils with $\mathrm{PMJ}$ and $\mathrm{CA}$, respectively. Thus, indicating that incorporation of organic materials and $\mathrm{P}$ could save some amount of soil available-P over time.

\subsection{PHOSPHORUS REQUIREMENT OF WHEAT}

The efficiency with which $\mathrm{P}$ is utilized to produce yield is the amount of $\mathrm{P}$ needed in the plant to produce one unit of dry matter (Loneragan \& Asher, 1967). The solution $\mathrm{P}$ levels developed for wheat growth were plotted against $95 \%$ relative yield of wheat for the determination of $\mathrm{P}$ requirement by the Boundary Line Technique (Ur-Rehman et al., 2002). Phosphorus efficiency is therefore often called external $\mathrm{P}$ requirement i.e. the $\mathrm{P}$ content in soil required to produce $95 \%$ of maximum yield. The graph revealed that a lower external $\mathrm{P}$ requirement of 0.195 and $0.245 \mathrm{mg} \mathrm{P}^{-1}$ may be required in CA and PMJ treatments, compared to the control treatments $\left(0.345 \mathrm{mg} \mathrm{Pl}^{-1}\right)$ for near maximum yield of wheat (95 \%) (Fig. 2). Our results revealed that external (solution) P requirement or critical $\mathrm{P}$ solution concentration was in gener-
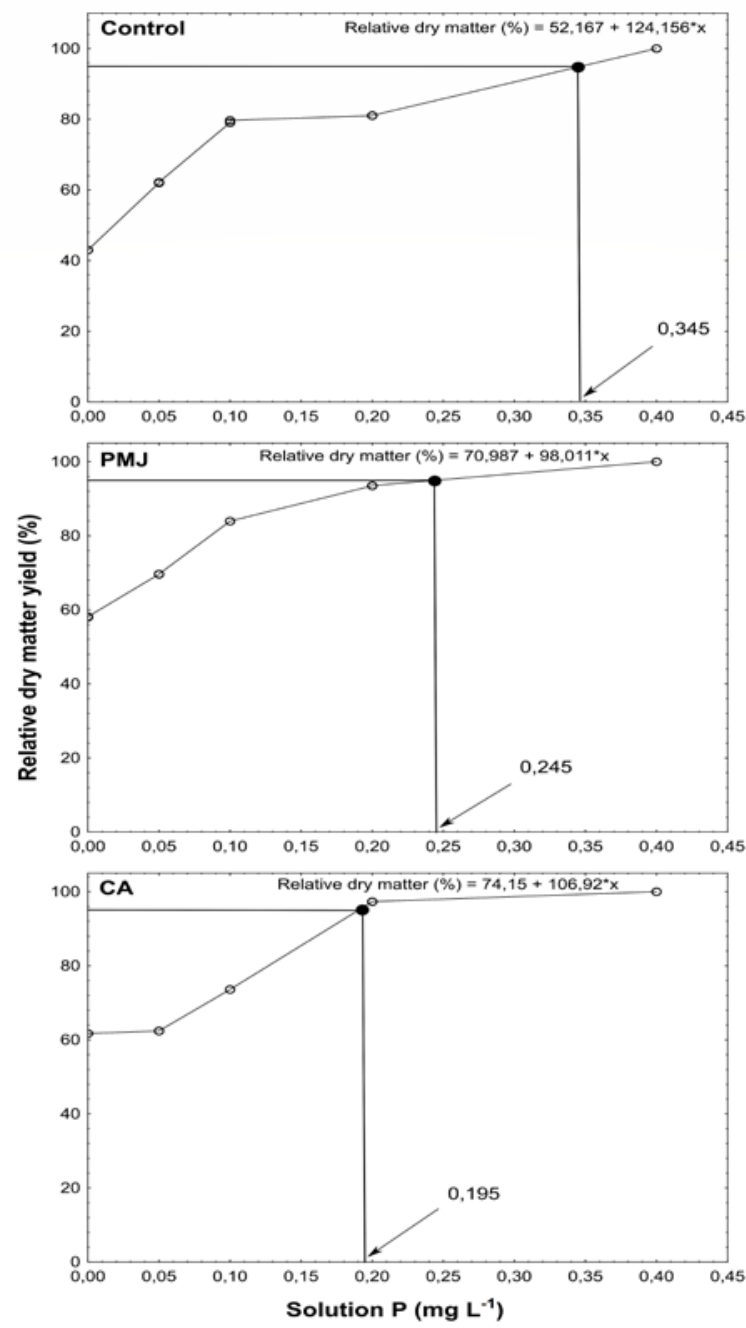

Figure 2: External P requirement associated with $95 \%$ relative shoot dry matter yield of wheat 
al near to $0.20 \mathrm{mg} \mathrm{l}^{-1}$ reported in the literature to be a threshold for many crops, over which no response to $\mathrm{P}$ is observed (Iyamuremye et al., 1996; Nziguheba et al., 1998; Duffera \& Robarge, 1999). Sarfraz et al. (2008) recorded $0.27 \mathrm{mg} \mathrm{P} \mathrm{l}^{-1}$ as the $\mathrm{P}$ requirement to produce $95 \%$ of maximum yield in a calcareous soil. In this study, amended soil recorded lower values of external $\mathrm{P}$ requirement over control. Accordingly, the near maximum yield of wheat $(95 \%)$ was obtained at lower solution $\mathrm{P}$ level. This might mean that $\mathrm{P}$ availability was greater after combining $\mathrm{P}$ fertilizers with organic substances. These results are corroborated by the findings of Mihoub et al. (2017) who reported that the application of low molecular mass organic acids along with $\mathrm{P}$ fertilizer decreased the $\mathrm{P}$ requirements in a calcareous-alkaline soil.

\subsection{PHOSPHORUS ABSORPTION EFFICIENCY}

The $\mathrm{P}$ absorption efficiency is an important index in determining use of applied fertilizer by a crop. PAE refers to the ability of crops to take up P from soils. Enhanced $\mathrm{P}$ efficiency can be achieved by improved uptake of phosphate from soil (PAE) and by improved productivity per unit P taken up (PUE) (Veneklaas et al., 2012). Compared to the control treatment, all treatments and their combination with organic substances caused significant increases in phosphorus absorption efficiency $(p<0.01)$. Figure 3 shows that PAE was higher in the CA than PMJ treatments and increased with increasing $\mathrm{P}$ level. Data regarding PAE in the control pots was $0.26 \mathrm{mg} \mathrm{mg}^{-1}$ soil P. However, an average of 0.39 and $0.45 \mathrm{mg} \mathrm{mg}^{-1}$ soil $\mathrm{P}$ were recorded in amended pots with $\mathrm{PMJ}$ and CA, respectively.

The phosphorus absorption efficiency increased with both organic substances and it was higher in the CA than PMJ treatments and increased with increasing $\mathrm{P}$ levels. Integration of $\mathrm{P}$ fertilizer with organic substances increased PAE by wheat as 50 and $73 \%$ by PMJ and CA treatments, respectively over the control. This may be related to the strong relationship between PAE and wheat P uptake.

\section{CONCLUSION}

Actually, there is an urgent need to seek strategies by which $\mathrm{P}$ fertilizers can be used more effectively in different soil types such as calcareous soils where $\mathrm{P}$ is currently deficient and where its use is economically feasible. In the current study, the integration of mineral P fertilizers with organics substances showed an improvement of the soil productivity by enhancing the bioavailability of phosphorus and its use efficiency by wheat plants. We recommend fertilizing the calcareous soils via $P$ fertilizers and low-cost organic supplements such as poultry manure juice; this would be conducive to increase phosphorus adsorption efficiency and reduce the use of chemical fertilizers without compromise on yields.

\section{REFERENCES}

Acuña, H., \& Inostroza. L. (2012). Phosphorus efficiency of nat-

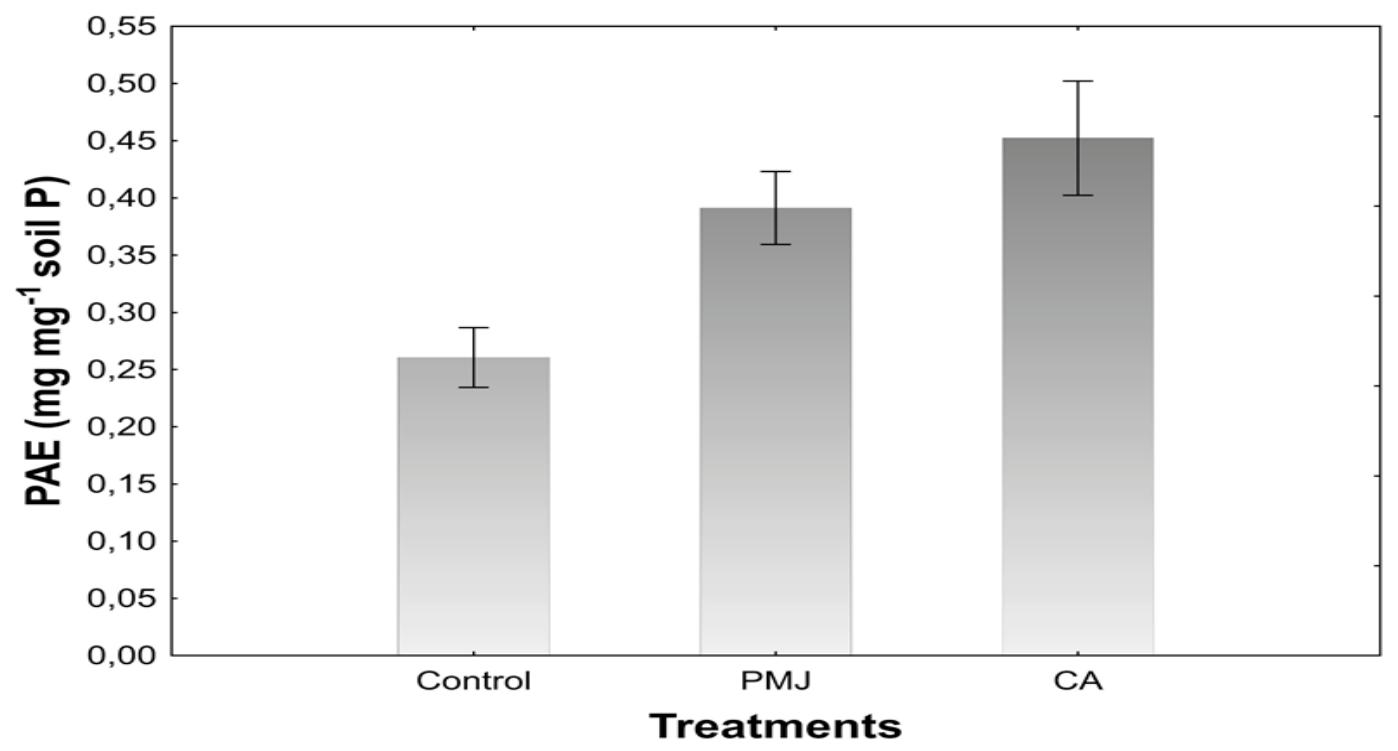

Figure 3: Phosphorus adsorption efficiency by wheat as affected by different treatments. Vertical bars denote \pm standard deviation 
uralized Chilean white clover in a grazed field trial. Grass and Forage Science, 68, 125-137. https://doi.org/10.1111/ j.1365-2494.2012.00879.x

Agbenin, J. O., \& Igbokwe, S. O. (2006). Effect of soil-dung manure incubation on the solubility and retention of applied phosphate by a weathered tropical semi-arid soil. Geoderma, 133, 191-203. https://doi.org/10.1016/j.geoderma.2005.07.006

Alamgir, M., McNeill, A., Tang, C., \& Marschner, P. (2012). Changes in soil $\mathrm{P}$ pools during legume residue decomposition. Soil Biology and Biochemistry, 49, 70-77. https://doi. org/10.1016/j.soilbio.2012.01.031

Amin, A. A. (2018). Availability and transformations of phosphorus in calcareous sandy soil as affected by farmyard manure and elemental sulfur applications. Alexandria Science Exchange Journal, 39, 98-111. https://doi.org/10.21608/asejaiqjsae.2018.5795

Brady, N. C., \& Weil, R. R. (1999). The Nature and Properties of Soils. $12^{\text {th }}$ Ed. Pearson Prentice Hal Inc. Upper Saddle River, New Jersey. USA.

Brady, N. C., \& Weil, R. R. (2008). The Nature and Properties of Soils. Revised $14^{\text {th }}$ Ed. Pearson Prentice Hal Inc. Upper Saddle River, New Jersey. USA.

Bulgari, R., Cocetta, G., Trivellini, A., Vernieri, P., \& Ferrante, A. (2014). Biostimulants and crop responses: a review. Biological Agriculture and Horticulture, 31, 1-17. https://doi.or g/10.1080/01448765.2014.964649

Deng, Y., Chen, K., Teng, W., Zhan, A., \& Tong, Y. (2014). Is the Inherent Potential of Maize Roots Efficient for Soil Phosphorus Acquisition? PLoS ONE. 9. e90287. https://doi. org/10.1371/journal.pone.0090287

Duffera, M., \& Robarge, W. P. (1999). Soil characteristics and management effects on phosphorus sorption by highland plateau soils of Ethiopia. Soil Science Society of America Journal, 63, 1455-1462. https://doi.org/10.2136/ sssaj1999.6351455x

Fox, R. L., \& Kamprath, E. J. (1970). Phosphate sorption isotherm for evaluating the phosphate requirements of soils. Soil Science Society of America. Proceedings, 34, 902-907. https://doi.org/10.2136/sssaj1970.03615995003400060025x

Gichangi, E. M., \& Mnkeni, P. N. S. (2009). Effects of goat manure and lime addition on phosphate sorption by two soils from the Transkei Region. South Africa. Communications in Soil Science and Plant Analysis, 40, 3335-3347. https:// doi.org/10.1080/00103620903325943

Grant, C. S., Bittman, M., Montreal, C., Plenchette., \& Morel, C. (2004). Soil and fertilizer phosphorus: Effects on plant P supply and mycorrhizal development. Canadian Journal of Plant Science, 85, 3-14. https://doi.org/10.4141/P03-182

Guppy, C. N., Menzies, N. W., Moody, P. W., \&Blamey, F. P. C. (2005). Competitive sorption reactions between phosphorus organic matter in soil: A review. Australian Journal of Soil Research, 43, 189-202. https://doi.org/10.1071/SR04049

Heidi, M. W., He. Z., \& Erich, M. S. (2011). Effects of poultry manure amendment on phosphorus uptake by rye grass. soil phosphorus fraction and phosphatase activity. Biology and Fertility of Soils, 47, 407-418. https://doi.org/10.1007/ s00374-011-0546-4
Ingham, E. R. (2002). The Compost tea brewing manual. $3^{\text {rd }}$ Edition. Oregon. USA: Soil Food web Inc.

Iyamuremye, F., \& Dick, R. P. (1996). Organic amendments and phosphorus sorption by soils. Advances in Agronomy, 56, 139-185. https://doi.org/10.1016/S0065-2113(08)60181-9

Javid, S., \& Rowell, D. L. (2002). A laboratory study of the effect of time and temperature on the decline in Olsen $\mathrm{P}$ following phosphate addition to calcareous soils. Soil Use and Management, 18, 127-134. https://doi. org/10.1111/j.1475-2743.2002.tb00230.x

Kelly, J. M., Parker, G. R., \& Mcfee, W. W. (1979). Heavy metal accumulation and growth of seedling of five species as influenced by soil cadmium level. Journal of Environmental Quality, 8, 361-364. https://doi.org/10.2134/ jeq1979.00472425000800030019x

Kizilgoz, I., \& Sakin, E. (2010). The effects of increased phosphorus application on shoot dry matter, shoot $\mathrm{P}$ and $\mathrm{Zn}$ concentrations in wheat (Triticum durum L.) and maize (Zea mays L.) grown in a calcareous soil. African Journal of Biotechnology, 9, 5893-5896.

Li, W., Li, L., Sun, J., Zhang, F., \& Christie, P. (2003). Effects of nitrogen and phosphorus fertilizers and intercropping on uptake of nitrogen and phosphorus by wheat, maize, and faba bean. Journal of Plant Nutrition, 26, 629-642. https:// doi.org/10.1081/PLN-120017670

Loeppert, R. H., \& Dohnal, V. (1996). Methods of Soil Analysis, Part 3. Chemical Methods. SSSA Book series No. 5. Madison, WI.

Loneragan, J. F., \& Asher, C. J. (1967). Response of plants to phosphate concentration in solution culture. II. Rate of phosphate absorption and its relation to growth. Soil Science, 103, 311-318. https://doi.org/10.1097/00010694196705000-00002

Ma, B. G., Yang, T. X., Guo, F. T., \& Han, J. J. (2005). Balance of phosphorus in a rotation system with winter-wheat and rice. Journal of Agro-Environment Science, 2, 371-374.

Ma, L., \& Xu, R. (2010). Effects of regulation of $\mathrm{pH}$ and application of organic material on adsorption and desorption of phosphorus in three types of acid soils. Journal of Ecology and Rural Environment, 26, 596-599.

Mehdi, S. M., Abid, M., Sarfraz, M., Hafeez, M., \& Hafeez, F. (2007). Wheat response to applied phosphorus in Light Textured Soil. Journal of Biological Sciences, 7, 1535-1538. https://doi.org/10.3923/jbs.2007.1535.1538

Mihoub, A., Daddi Bouhoun, M., \& Naeem, A. (2018). Shortterm effects of phosphate fertilizer enriched with low molecular weight organic acids on phosphorus release kinetic and availability under calcareous conditions in arid region. Journal of Scientific Agriculture, 2, 66-70. https://doi. org/10.25081/jsa.2018.v2.884

Mihoub, A., Daddi Bouhoun, M., \& Saker, M. L. (2016). Phosphorus adsorption isotherm: A key aspect for effective use and environmentally friendly management of phosphorus fertilizers in calcareous soils. Communications in Soil Science and Plant Analysis, 47, 1920-1929. https://doi.org/10.1 080/00103624.2016.1206923

Mihoub, A., Daddi Bouhoun, M., Naeem, A., \& Saker, M. L. (2017). Low-molecular weight organic acids improve plant availability of phosphorus in different textured calcareous 
soils. Archives of Agronomy and Soil Science, 63, 1023-1034. https://doi.org/10.1080/03650340.2016.1249477

Mohanty, S., Paikaray, N. K., \& Ranjan, A. R. (2006). Availability and uptake of phosphorus from organic manures in groundnut (Arachis hypogea L.)-corn (Zea mays L.) sequence using radio tracer technique. Geoderma, 133, 225230. https://doi.org/10.1016/j.geoderma.2005.07.009

Moradi, N., Sadaghiani, M. R., Sepehr. E., \& Mandoulakani, B. A. (2012). Effects of low-molecular-weight organic acids on phosphorus sorption characteristics in some calcareous soils. Turkish Journal of Agriculture and Forestry, 36, 459468.

Nziguheba, G., Palm, C. A., Buresh, R. J., \& Smithson, P. A. (1998). Soil phosphorus fractions and adsorption as affected by organic and inorganic sources. Plant and Soil, 198, 159-168. https://doi.org/10.1023/A:1004389704235

Pellerin, S., Mollier, A., Plénet, D. (2000). Phosphorus deficiency affects the rate of emergence and number of maize adventitious nodal roots. Agronomy Journal, 92, 690-697. https://doi.org/10.2134/agronj2000.924690x

Pinerio, A. L., Cabera, D., \& Pena, D. (2009). Phosphorus Adsorption and fractionation in a two-phase olive mill waste amended soil. Soil Science Society of America Journal, 73, 1539-1544. https://doi.org/10.2136/sssaj2009.0035

Royo, C., Soriano, J. M., \& Alvaro, F. (2017). Wheat: A Crop in the Bottom of the Mediterranean Diet Pyramid. In Mediterranean Identities-Environment, Society, Culture. IntechOpen. https://doi.org/10.5772/intechopen.69184

Sarfraz, M., Mehdi. S. M., Abid, M., \& Akram, M. (2008). External and internal phosphorus requirement of wheat in Bhalike soil series of Pakistan. Pakistan journal of Botany, 40, 2031-2040.

Ström, L., Owen, A., Godbold, D., \& Jones, D. (2001). Organic acid behavior in a calcareous soil: sorption reactions and biodegradation rates. Soil Biology \& Biochemistry, 33, 2125 2133. https://doi.org/10.1016/S0038-0717(01)00146-8

Uburger, E., Jones, D. L., \& Wenzel, W. W. (2011). Phosphorus saturation and $\mathrm{pH}$ differentially regulate the efficiency of organic acid anion- mediated P solubilization mechanisms in soil. Plant and Soil, 341, 363-382. https://doi.org/10.1007/ s11104-010-0650-5

Ur-Rehman, O., Mehdi, S. M., Ranjha, A. M., Sarfraz, M., Zulfiqar, A. M., Asim, M., \& Quintero, G. C. E. (2002). Use of boundary line technique in the analysis of biology data. Journal of Biological Sciences, 7, 60-63.

Veneklaas, E. J., Lambers, H., Bragg, J., Finnegan, P. M., Lovelock, C. E., Plaxton, W. C., \& Raven, J. A. (2012). Opportunities for improving phosphorus-use efficiency in crop plants. New Phytologist, 195, 306-320. https://doi. org/10.1111/j.1469-8137.2012.04190.x

Von Wandruszka, R. (2006). Phosphorus retention in calcareous soils and the effect of organic matter on its mobility. Geochemical Transactions, 7, 1-18. https://doi. org/10.1186/1467-4866-7-6

Waraich, E. A., Ahmad, Z., Ahmad, R., Saifullah., \& Ashraf, M. Y. (2015). Foliar applied phosphorous enhanced growth. chlorophyll contents. gas exchange attributes and PUE in wheat (Triticum aestivum L.). Journal of plant nutrition, 38, 1929-1943. https://doi.org/10.1080/01904167.2015.104337 7

Watanabe, F. S., \& Olsen, S. R. (1965). Test of an ascorbic acid method for determining phosphorus in water and $\mathrm{NaHCO}_{3}$ extracts from soil 1. Soil Science Society of America Journal, 29, 677-678. https://doi.org/10.2136/ sssaj1965.03615995002900060025x 